\title{
Innovation in Food Access Amid the COVID-19 Pandemic
}

\author{
Jessica A. Carson
}

The Carsey Perspectives series presents new ways of looking at issues affecting our society and the world. Any opinions, findings, and conclusions or recommendations expressed in this material are those of the authors and do not necessarily reflect the views of the sponsors or publisher.

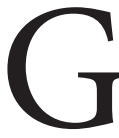
overnment agencies, nonprofit organizations, and volunteer networks are undertaking innovative efforts during the COVID-19 pandemic to ensure food access by vulnerable populations. By highlighting strategies that are unfolding in real time, this brief shares an array of potential approaches for private, public, and nonprofit stakeholders to use in deploying their resources.

\section{Strengthening Emergency Food Systems}

One sector especially quick to respond to the pressures created by the pandemic has been the nonprofit emergency food safety net. Amid rising unemployment and the closure of nutrition support sites like school cafeterias, demand for food support through nonprofit safety nets has spiked, and food pantries and food banks are experiencing unprecedented increases in volume. ${ }^{1}$

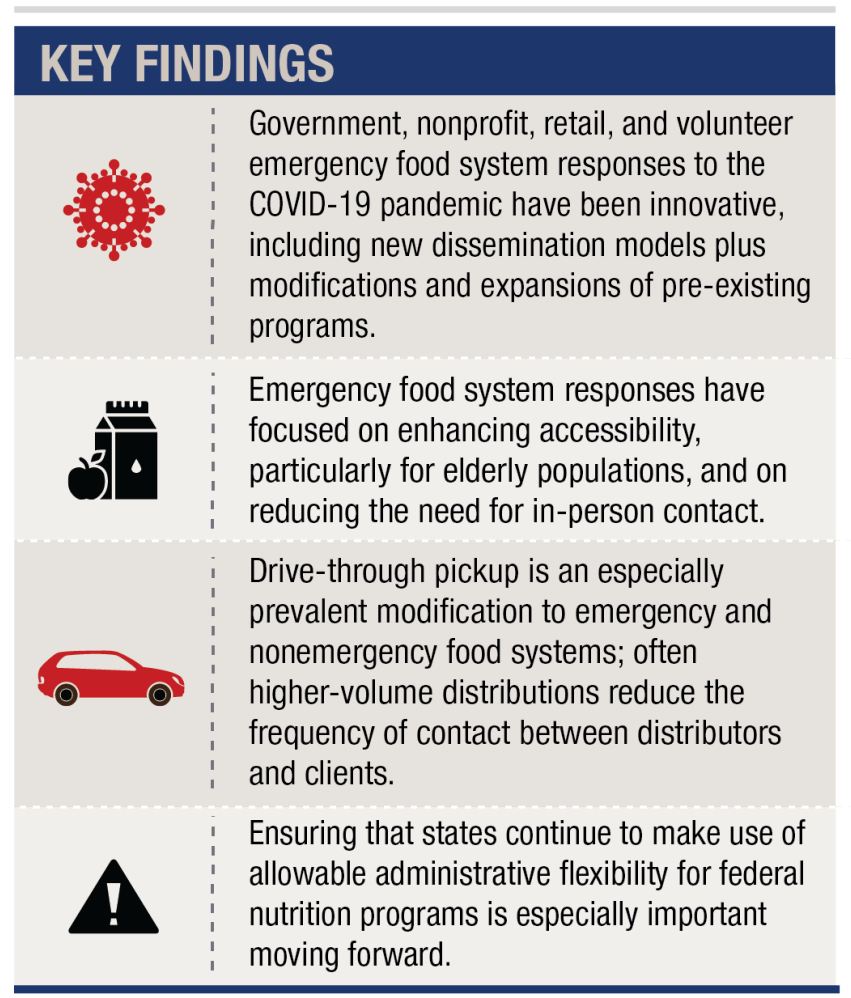

\section{TABLE 1. EMERGENCY FOOD SYSTEM RESPONSES TO COVID-19 PANDEMIC}

\begin{tabular}{l|l}
\hline Model & Components \\
\hline $\begin{array}{l}\text { Drive-through or curbside } \\
\text { food pantry pickup }\end{array}$ & $\begin{array}{l}\text { Prepackaged boxes of food are placed in cars, }{ }^{2} \text { or clients can } \\
\text { select from a list of available items that are then collected and } \\
\text { brought outside by workers }\end{array}$ \\
\hline Mobile food pantries & $\begin{array}{l}\text { Trucks carrying prepacked food travel to community locations } \\
\text { more accessible than the usual food pantry }\end{array}$ \\
\hline Informal food pantries & $\begin{array}{l}\text { Freestanding outdoor cupboards are set up on public or private } \\
\text { properties; they are available to anyone, open at all hours, and } \\
\text { operate with a "take what you need, give what you can" basis; }\end{array}$ \\
they include "Blessings Boxes"6 and "Little Free Pantries"7 \\
Modified Meals-on- \\
$\begin{array}{l}\text { Seniors receive delivery of multiple meals (some frozen) at } \\
\text { once, }{ }^{8} \text { reducing the daily contact required under usual model }\end{array}$ \\
\hline $\begin{array}{l}\text { Grab-and-go senior } \\
\text { meals }\end{array}$ & $\begin{array}{l}\text { Replacing congregate meals, these models provide food to } \\
\text { seniors who may not meet the criteria for home delivery }\end{array}$ \\
\hline $\begin{array}{l}\text { Restaurant-delivered } \\
\text { meals }\end{array}$ & $\begin{array}{l}\text { Local governments pair older adults and other eligible } \\
\text { individuals unable to cook with underutilized restaurants }\end{array}$ \\
\hline
\end{tabular}

Table 1 shows some of the varied responses by these emergency food systems to the jump in demand that is occurring at a time of increased social distancing.

Even in normal times, food pantries are responsive to the characteristics and needs of their communities, and this is true of pandemic responses too. Dissemination via prepackaged boxes allows for bulk distribution, while the option to make selections and then pick them up curbside can be useful in communities with special dietary needs. Mobile food pantries may be especially useful for reaching those with transportation limitations, including people 
who once relied on now-closed public transit or those in very rural places. Sometimes mobile pantries are paired with other services, like COVID-19 testing. ${ }^{11}$

To support increased levels of need, the Families First Coronavirus Response Act (FFCRA) designated $\$ 400$ million in funding for the Emergency Food Assistance Program to support food banks. ${ }^{12}$ In part to ease supply pressures, in mid-April the U.S. Department of Agriculture (USDA) announced it would attempt to address the mismatch between the glut of unharvested and unsold farm food and the food needs of families by creating the Farmers to Families Food Box program, which partners with local distributors to purchase food from farmers, repackage it into family-sized boxes, and distribute it to food pantries and other nonprofits for dissemination. ${ }^{13}$ More than $\$ 1.2$ billion in contract awards were announced May 8, 2020, ${ }^{14}$ with purchases expected to begin in midMay. ${ }^{15}$ FFCRA also designated $\$ 250$ million to support senior nutrition programs, ${ }^{16}$ and the Coronavirus Aid, Relief, and Economic Security (CARES) Act $^{17}$ designated $\$ 500$ million to bolster resources for especially high-risk populations.

\section{Rapidly Shifting School Meal Distribution Plans}

With school closures in effect, individual districts and child-serving nonprofits have had to rapidly adjust their meal distribution systems to ensure that students remain fed. Specific strategies for doing so are listed in Table 2.

The changes to school meal delivery systems, which have been implemented quickly and widely, were aided by the FFCRA, which allowed the USDA to loosen requirements

\begin{tabular}{|c|c|}
\hline Model & Components \\
\hline Bus-stop or home delivery & $\begin{array}{l}\text { Students are delivered school meals, sometimes in weekly } \\
\text { batches, to their usual bus stops or their homes }{ }^{18}\end{array}$ \\
\hline Grab-and-go meal pickup & $\begin{array}{l}\text { Meals are available for pickup at a central location, usually the } \\
\text { school, at designated times; families are encouraged to practice } \\
\text { social distancing at pickup }{ }^{19}\end{array}$ \\
\hline Weekend meal services & $\begin{array}{l}\text { Nonprofits continue to feed students outside of school hours by } \\
\text { connecting with school distribution efforts to provide prepacked } \\
\text { bags of food for consumption over the weekend }{ }^{20}\end{array}$ \\
\hline
\end{tabular}

around school meal components and delivery settings. Many of these strategies are expected to continue into summer; in March, the Food and Nutrition Service began approving waivers to enable sponsors of the Summer Food Service Program and the National School Lunch Program Seamless Summer Option to serve meals in a noncongregate setting. ${ }^{21}$ However, preparing and delivering meals under these new models is expensive for schools, especially since reaching all eligible students is a challenge and schools (or other sponsors, if a summer program ${ }^{22}$ are reimbursed on a per-meal-served basis, with no dedicated reimbursements to account for new delivery costs. Some administrators have expressed concerns about resulting budget shortfalls, which are likely to materialize in the next school year when demand for free and reduced-price lunch may continue to rise. ${ }^{23}$

\section{Increasing Resources for Individuals' Food Spending}

In addition to bolstering resources for emergency food and school nutrition, the FFCRA also put in place several administrative flexibilities related to nutrition programs that aim to make more food-spending money available to consumers. These flexibilities are summarized in Table 3.

Given the responsiveness of the Supplemental Nutrition Assistance Program (SNAP) to economic downturns, serving more low-income households during a downturn and fewer during times of expansion, ${ }^{28}$ changes to the program under the FFCRA are especially important. Emergency allotments to SNAP households provide low-income families with immediate food purchasing power and free up household resources for other necessities.

\section{TABLE 3. STRATEGIES FOR INCREASING FOOD SPENDING CAPACITY IN} RESPONSES TO COVID-19 PANDEMIC

\begin{tabular}{l|l}
\hline Model & Components \\
$\begin{array}{l}\text { SNAP emergency } \\
\text { allotments }\end{array}$ & $\begin{array}{l}\text { States can provide households with temporary benefits up to the } \\
\text { monthly maximum amount }{ }^{24}\end{array}$ \\
$\begin{array}{l}\text { SNAP administrative } \\
\text { changes }\end{array}$ & $\begin{array}{l}\text { Time limits on eligibility for unemployed and underemployed recipients } \\
\text { are suspended; states have flexibility in certification processes }\end{array}$ \\
\hline Pandemic EBT & $\begin{array}{l}\text { The value of lost school meals is recouped through electronic benefit } \\
\text { transfer allocations for families }\end{array}$ \\
\hline Grocery store vouchers & $\begin{array}{l}\text { Families receive gift cards or vouchers from local government or } \\
\text { nonprofit agencies }{ }^{27}\end{array}$ \\
\hline
\end{tabular}


Administrative changes easing requirements around reporting, certification, and in-person interviews and signatures support consistency of access in this unprecedented time while also conserving state administrative resources and reducing the need for in-person contact between caseworkers and clients.

Importantly, nonfederal efforts to increase families' food budgets are also in play. For instance, Seattle, WA provided $\$ 800$ grocery store vouchers to 6,000 low-income families identified through their enrollment in existing city child care subsidy and food assistance programs; the voucher is funded through the city's soda tax revenue. ${ }^{29}$ Other nonprofit agencies have also provided direct grocery store voucher assistance, including through the United Way. ${ }^{30}$

\section{Innovating Food Acquisition Strategies}

Unlike in prior economic downturns, meeting food needs is not limited to supplementing food purchasing power or ensuring sufficient charitable donations. In the pandemic context, it has also been key to alter food acquisition channels to comply with social distancing regulations and to address access issues for those at elevated risk of infection. Some of these strategies are listed in Table 4.

\section{TABLE 4. FOOD ACQUISITION SYSTEM RESPONSES TO COVID-19 PANDEMIC}

\begin{tabular}{l|l}
\hline Model & Components \\
$\begin{array}{l}\text { Social distancing in } \\
\text { grocery settings }\end{array}$ & $\begin{array}{l}\text { Reduced stores capacities; dedicated hours for vulnerable shoppers; } \\
\text { aisle closures and markers; }{ }^{31} \text { expanded online ordering, delivery, and } \\
\text { curbside pickup }\end{array}$ \\
\hline Mutual aid groups ${ }^{32}$ & $\begin{array}{l}\text { Errands run for vulnerable populations by local volunteer networks; } \\
\text { grocery delivery for seniors often included }{ }^{33}\end{array}$ \\
\hline $\begin{array}{l}\text { Direct-to-consumer } \\
\text { sales }\end{array}$ & $\begin{array}{l}\text { Food producers sell directly to consumers; producers receive income, } \\
\text { consumers allowed to shop in a less-populated setting }\end{array}$ \\
\hline
\end{tabular}

where larger grocery delivery services are unavailable or goods are out of stock..$^{38}$ By selling directly to consumers, local producers can recoup some of the losses that might be sustained from having fewer wholesale buyers, although this option is unlikely to help mid-size and larger farmers, who are not equipped to package and distribute directly to consumers. ${ }^{39}$

\section{How Policy Can Continue Supporting Access}

As the pandemic continues to affect families' economic wellbeing, food access is likely to remain an important challenge. One immediate action for states to take is to utilize the flexibility afforded under USDA program options and waivers, including relaxing administrative rules around SNAP and applying to operate a Pandemic Electronic Benefit Transfer (EBT) program. ${ }^{40}$ The Center on Budget and Policy Priorities notes, however, that there is substantial variation in states' uptake of these waivers and options, with all states opting to provide SNAP recipients with an emergency allotment, many states adjusting requirements around certification and reporting, and several states applying to run Pandemic EBT programs. ${ }^{41}$

In addition to adjustments to existing programs, a pilot program that allows SNAP users to shop online is underway now, with the pressures of the pandemic expediting the planned rollout into additional states. ${ }^{42}$ Although the extent of the pandemic's toll on unemployment and household income is not yet clear, it is possible that additional flexibilities around SNAP benefit levels and eligibility may be 
relevant for supporting food access, as will be additional federal allocations for other nutrition programs like the Special Supplemental Nutrition Program for Women, Infants, and Children, commonly known as WIC.

\section{About the Author}

Jess Carson is a research assistant professor with the Vulnerable Families Research Program at the Carsey School of Public Policy. Since joining Carsey in 2010, she has studied poverty, work, and the social safety net, including policies and programs that support lowincome workers like affordable health insurance, food assistance programs, and quality child care.

\section{Acknowledgments}

The author thanks Michael Ettlinger and Sarah Boege at the Carsey School of Public Policy, Helen Costello at Costello Food Systems and Nutrition Consulting, and Grace Stott at the University of New Hampshire for feedback on an earlier draft; Patrick Watson for editorial assistance; and Laurel Lloyd and Nick Gosling at the Carsey School for support with layout and digital components.

\section{Endnotes}

1. https://www.sentinelsource.com/ news/local/nh-food-bank-rise-in-needputs-strain-on-food-pantries-aroundthe-state/article_05769e6d-a06e-505eb3fd-79d230510df0.htm

2. https://www.nytimes.com/2020/04/08/ business/economy/coronavirus-foodbanks.html

3. https://www.fosters.com/ news/20200427/community-foodpantry-is-here-to-help-during-covid-19

4. https://www.sunherald.com/news/ local/counties/hancock-county/ article242432891.html; https://www. wmur.com/article/nh-food-bankhelps-over-500-families-with-amobile-pantry/32353108; https://www. nbcdfw.com/news/coronavirus/mobilepantries-food-drives-feed-familiesstruggling-during-covid-19/2362256/

5. It is worth noting, however, that there is at least one instance of a person being ordered by her county health department to desist operation of an informal free pantry. https://reason. com/2020/05/01/a-washington-womanset-up-a-little-free-pantry-withouta-permit-asotin-county-threatenedcriminal-charges/

6. https://www.wspa.com/news/ spartanburg-blessing-box-in-needof-more-supplies-as-covid-19pandemic-increases-demand/; https:// islandfreepress.org/outer-banks-news/ fair-haven-umc-installs-blessingbox-for-tri-villages/; https://www. nny360.com/communitynews/ communitygiving/a-new-blessing-boxin-mexico/article_21b9b470-378a5de3-8425-5945a391657d.html

\section{7. http://www.littlefreepantry.org/}

8. https://www.victoriaadvocate.com/ covid-19/demand-for-meals-onwheels-reaches-unprecedented-levelsamid-covid-19/article_ec38759c-8e3511ea-a91a-3be96bccf864.html

9. https://straffordmealsonwheels. org/covid-19-response; https:// thetandd.com/news/local/orangeburgcalhoun-county-seniors-offered-free- meals-due-to-covid-19-pandemic/ article_1795b26f-2f39-5e4f-a3c0ecc949fb87d0.html

10. https://covid19.lacounty.gov/getsupport/

11. https://wreg.com/news/testing-sitedoubles-as-mobile-food-pantry-insouth-memphis/

12. https://www.feedingamerica. org/about-us/press-room/feedingamerica-senate-passage-families-firstcoronavirus-response-act

13. The challenges facing farmers, including migrant labor shortages and major gaps in distribution channels, are critically important to understanding the food chain but outside of the scope here. For more on the Farmers to Families Food Box program, see https://www.ams.usda.gov/selling-foodto-usda/farmers-to-families-food-box; https://www.morningagclips.com/ details-on-farmers-to-families-foodbox-program/; and https://abcnews. go.com/Politics/usda-farmers-feedfamilies-advocates-lawmakers/ story? $\mathrm{id}=70453021$. For more on the food supply chain disruptions related to farms, see https://civileats. com/2020/04/15/food-distribution101-what-happens-when-the-foodsupply-is-disrupted-by-a-pandemic and https://www.csis.org/programs/globalfood-security-program/covid-19-andfood-security.

14. https://www.ams.usda. gov/sites/default/files/media/ AnnouncementofContractAwards. pdf. It is worth noting that some produce industry experts have expressed concern over the capacity for contracted agencies to fulfill the program's goals. See, for example, https://www.thepacker.com/article/ industry-questions-farmers-familiesfood-box-awards and https://www. politico.com/news/2020/05/13/usdafood-bank-contracts-256452.

15. https://www.bloomberg.com/news/ articles/2020-05-09/usda-s-food-boxprogram-to-ramp-up-next-weektrump-says 
16. https://www.mealsonwheelsamerica. org/learn-more/national/press-room/ news/2020/03/19/250-million-inemergency-funding-signed-into-law

17. https://www.mealsonwheelsamerica. org/take-action/covid-19-response

18. https://www.spps.org/covidmeals; https://www.hazelwoodschools.org/ Page/7455; https://foodcorps.org/schoolnutrition-heroes-on-the-front-lines-ofcovid-19/; https://spotlightonpoverty. org/spotlight-exclusives/strengtheningschool-nutrition-in-the-face-of-covid-19/

19. https://www.horrycountyschools. net/Page/15249; https://aist. com/2020/04/28/lausd_free_meals_ coronavirus_budget.php

20. https://www.blessingsinabackpack. org/covid-19-response-effort/

21. https://www.fns.usda.gov/sfsp/ covid-19/covid-19-meal-delivery

22. https://frac.org/wp-content/ uploads/sfsp_fact_sheet.pdf

23. https://www.huffpost.com/entry/ school-lunch-programs-coronavirusdebt_n_5e9a0fc4c5b635d25d6c635a

24. https://frac.org/news/foodresearch-action-center-commends-thehouse-for-passing-the-families-firstcoronavirus-response-act

25. https://frac.org/news/foodresearch-action-center-commends-thehouse-for-passing-the-families-firstcoronavirus-response-act

26. https://www.fns.usda.gov/snap/stateguidance-coronavirus-pandemic-ebt-pebt

27. https://www.seattletimes.com/seattlenews/politics/seattle-will-provide-800in-supermarket-vouchers-to-thousandsof-families-during-coronavirus-crisis/; https://www.unitedwayofblaircounty. org/covid-19-emergency-relief-fundapplication; https://www.winknews. com/2020/04/15/red-sox-foundationoffers-250-food-aid-gift-cards-throughemergency-hardship-fund/

28. https://www.ers.usda.gov/topics/ food-nutrition-assistance/supplementalnutrition-assistance-program-snap/ economic-linkages/\#econactivity
29. https://www.seattletimes.com/ seattle-news/politics/seattle-willprovide-800-in-supermarket-vouchersto-thousands-of-families-duringcoronavirus-crisis/

30. https://www.unitedwayofblaircounty. org/covid-19-emergency-relief-fundapplication

31. https://www.nationalgrocers.org/ news/national-grocers-associationcoronavirus/

32. https://www.nytimes.com/2020/03/23/ opinion/coronavirus-aid-group.html

33. For a few examples, see http://connecticut.news12.com/ story/42046687/volunteer-firefightersets-up-a-grocery-delivery-service-inweston for an effort in Connecticut, https://cbs4local.com/news/local/ volunteer-grocery-delivery-programhelps-vulnerable-el-pasoans-shopfor-groceries for an effort in Texas, and https://newyork.cbslocal. com/2020/04/29/invisible-handsgrocery-delivery-coronaviruspandemic/ for one in New York.

34. https://www.nationalgrocers.org/ news/national-grocers-associationcoronavirus/

35. https://salinapost.com/ posts/5ea6f7e2eb7f1705360388e5

36. https://www.fosters.com/ news/20200427/fishermen-sellingfrom-boat-to-table-in-response-tocovid-19-challenges

37. https://www.concordmonitor.com/ lef-farms-hydroponics-nh-loudonnh-33997344

38. https://www.reuters.com/article/ us-health-coronavirus-usa-farmers/whoneeds-instacart-u-s-farmers-expandfood-deliveries-during-coronavirusoutbreak-idUSKBN21C1D3

39. Susan Geier, "Growing Pains," New Hampshire Business Review 42, no. 9 (2020): 8-9. https://issuu.com/ mcleancommunications/docs/nh_ business_review_may_8_2020/8
40. https://www.rand.org/blog/2020/03/ food-access-challenges-and-solutionsbrought-on-by.html; https://www. fns.usda.gov/snap/state-guidancecoronavirus-pandemic-ebt-pebt

41. https://www.cbpp.org/research/ food-assistance/most-states-are-usingnew-flexibility-in-snap-to-respond-tocovid-19

42. Note that in ten of the twelve states where online SNAP purchases are allowed, Amazon and Walmart are the only available retailers. https://www.fns. usda.gov/snap/online-purchasing-pilot 
6 CARSEY SCHOOL OF PUBLIC POLICY

\section{University of New Hampshire}

Carsey School of Public Policy

The Carsey School of Public Policy at the University of New Hampshire is nationally recognized for its research, policy education, and engagement. The school takes on the pressing issues of the twenty-first century, striving for innovative, responsive, and equitable solutions.

Huddleston Hall • 73 Main Street • Durham, NH 03824

(603) $862-2821$

TTY UsERS: DIAL 7-1-1 OR 1-800-735-2964 (RELAY N.H.)

carsey.unh.edu 